\title{
Pricing Schemes in Cloud Computing: An Overview
}

\author{
Artan Mazrekaj \\ Department of Computer \\ Engineering \\ Faculty of Electrical and Computer \\ Engineering \\ University of Prishtina \\ Prishtina, Republic of Kosovo
}

\author{
Isak Shabani \\ Department of Computer \\ Engineering \\ Faculty of Electrical and Computer \\ Engineering \\ University of Prishtina \\ Prishtina, Republic of Kosovo
}

\author{
Besmir Sejdiu \\ Department of Computer \\ Engineering \\ Faculty of Electrical and Computer \\ Engineering \\ University of Prishtina \\ Prishtina, Republic of Kosovo
}

\begin{abstract}
Cloud Computing is one of the technologies with rapid development in recent years where there is increasing interest in industry and academia. This technology enables many services and resources for end users. With the rise of cloud services number of companies that offer various services in cloud infrastructure is increased, thus creating a competition on prices in the global market. Cloud Computing providers offer more services to their clients ranging from infrastructure as a service (IaaS), platform as a service (PaaS), software as a service (SaaS), storage as a service (STaaS), security as a service (SECaaS), test environment as a service (TEaaS). The purpose of providers is to maximize revenue by their price schemes, while the main goal of customers is to have quality of services $(\mathrm{QoS})$ for a reasonable price. The purpose of this paper is to compare and discuss several models and pricing schemes from different Cloud Computing providers.
\end{abstract}

\section{Keywords-Cloud Computing; Pricing Models; Pricing Schemes}

\section{INTRODUCTION}

Cloud Computing is a new paradigm which has changed the traditional business schemes/plans and incorporating new economic and financial models of IT services market.

This technology allows end users to process, store and manage their data efficiently with fast and reasonably price.

Cloud computing customers do not need to install different software and they could access their data wherever they are via the Internet.

There are different definitions for Cloud Computing, Foster et al. [1] defines Cloud Computing as "a large-scale distributed computing paradigm that is driven by economies of scale, in which a pool of abstracted, virtualized, dynamicallyscalable, managed computing power, storage, platforms, and services are delivered on demand to external customers over the Internet".

Cloud Computing Providers offer numerous online services based on SLA (Service Level Agreement) between the provider and the customer.

However an important role between providers and customers relationship has pricing model for which they must agree.

Each provider has his scheme for calculating the price (has an accounting system) for the cloud services offered for clients. The provider's goal is to have a greater benefit, while each client's goal is to have the maximum service for low price.

Therefore, satisfying both parties requires an optimal pricing methodology. The price charged is one of the most important metrics that a service provider can control to encourage the usage of its services [2].

Price is an important factor for the company which provides cloud services because it affects the clients directly and organization profit.

The price also has a major impact in economic aspect, where key concepts such as fairness and competitive pricing in a multi-provider marketplace affect the actual pricing [18].

Pricing for competition and fairness affects choices in the design of user applications and system infrastructures.

In fact pricing fairness balances user cost and cloud service provider profit.

Pricing model in Cloud Computing is more flexible than traditional models. Every cloud provider has its own pricing scheme. Main focus of Cloud Computing is to fulfill and guarantee quality of service (QoS) for customers.

The price in Cloud Computing and value chain is based on business models and framework. The value chain from the traditional IT services is changing as a result of cloud computing.

This issue is illustrated from authors Jaekel and Luhn [30], which is shown in the figure below.

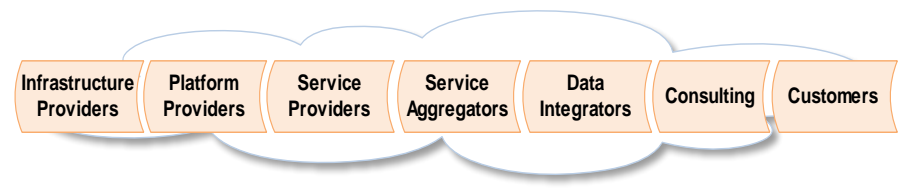

Fig. 1. Cloud Computing Value Chain

The key issue is how price / costs are measured, accounted, and distributed between different service layers and organizational units responsible of them.

There are many business models based on different service models that determine the price of services in the cloud. 
For example below we see an illustration of a model for Cloud Computing cost accounting [14] which addresses cost accounting issues in production of cloud services.

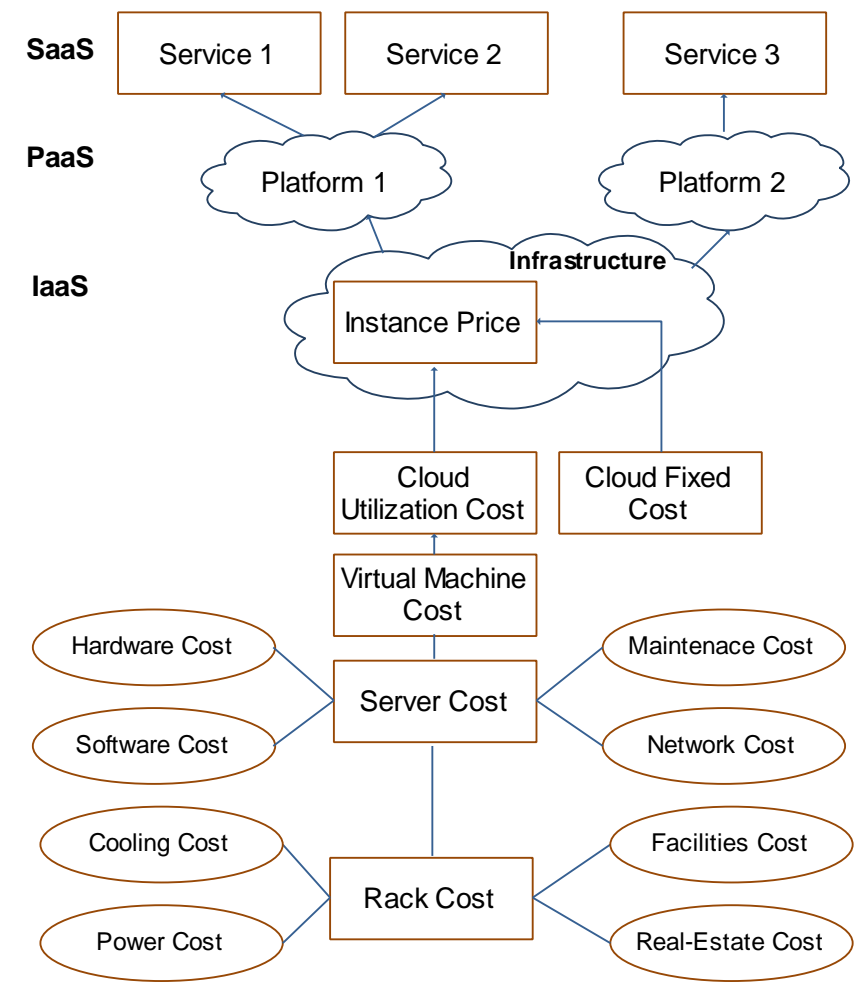

Fig. 2. Cloud Computing cost accounting model

In this paper we focus on review and comparing prices of some models, some pricing schemes which are provided by cloud service providers, based on services provided, their quality, fairness price and significance in the market.

\section{RELATED WORK}

In this section we discuss related work with regard to the pricing schemes in Cloud Computing.

The issue of price in the cloud in terms of relationship between providers and customers is treated by many authors, which have analyzed different schemes and models in theoretical aspects and simulated through different software.

Sharma et al., [3] proposed a novel financial economic model capable of providing a high level of QoS to customers.

They developed a financial option theory treating cloud resources as assets. The price determined by their model represents an optimal price where the provider charges the client in order to cover the initial cost.

Also, indirectly they have used Moore's law to determine the price of resources in the cloud and Black-Scholes-Merton (BSM) model that treats cloud resources as assets.

Through their experiments and simulations, they analyzed the effect of initial investment, effect of contract period, effect of rate of depreciation, effect of quality of service, effect of age of the resources on the resource price. The authors focused on the initial price however did not take under consideration the maintenance costs.

Patel and Shah [4] studied for prices caused by datacenters, which focused on three issues: space, power and cooling on cost model. They analyzed the price for each of the three cases and the sum of these prices to show a price comparison operating in datacenter. The authors of this study do not go any further in finding the cost of Cloud resources meant to be sold as a service.

Pal and Hui [5] have studied an economic model for fixing prices of resources. They used game theory and have presented some economic models. In first model, QoS guarantees provided by cloud provider are pre-specified and fixed competitors compete for prices. In another model, cloud providers compete for QoS level as well as prices for a particular application.

Wang et al. [6] proposed an algorithmic solution to optimize data center net profit with deadline-dependent scheduling by jointly maximizing revenues and minimizing electricity costs. They developed two distributed algorithms for the net profit optimization: Net Profit Optimization for Divisible jobs (NPOD), and Net Profit Optimization for Indivisible Jobs (NPOI). The authors proved via simulations their algorithm's capabilities to increase revenues and reduce electricity costs by comparing it to the Largest Job First (LJF) algorithm. The authors considered only static job arrivals and departures. They also assumed that the servers at all data centers were homogenous, which is not realistic [2].

Yeoa et al. [7] analyzed difference between fixed and variable prices. Fixed prices were easier to understand and more straightforward for users. However, fixed prices could not be fair to all users because not all users had the same needs. They proposed charging variable prices with advanced reservation, in which case users know the exact expenses that are computed at the time of reservation even though they were based on variable prices.

Macias and Guitart [8] proposed a genetic model for pricing in cloud computing markets. Choosing a good pricing model via their genetic algorithms involved three main steps: define a chromosome, evaluate it, and finally select the best pairs of chromosomes for reproduction and discarding those with the worst results. The results of the simulation illustrated that genetic pricing acquired the highest revenues in most of the scenarios. Service providers employing genetic pricing achieved revenues up to $100 \%$ greater than the other dynamic pricing strategies and up to $1000 \%$ greater than the fixed pricing strategy.

Li at al. [19] proposed a pricing algorithm for cloud computing resources. Authors proposed the cloud bank agent model as a resource agency from the global perspective, which provides analysis and guidance for all members.

The model analyses the historical utilization ratio of the resource, and iteration current prices constantly, get the availability of resources next time, the final price to users are expected to calculate. The proposed pricing model could not adapt to the rapid changes that occur in the market. 


\section{PRICING SCHEMES IN THE CLOUD}

Here we present an overview of pricing schemes from the perspective of the accounting process and the relevance from the business model. There are various pricing schemes depending on the cloud service provider. The challenge of service providers is to provide good services for reasonable price to users. The pricing should be based on customer's perceived value instead of production costs of services.

Some of the definitions and short description of pricing schemes and which vary depending on the services are [11]:

- Time based, pricing based on how long a service is used;

- Volume based, pricing based on the volume of a metric;

- Flat rate, a fixed tariff for a specified amount of time.

- Priority pricing, services are labeled and priced according to their priority;

- Edge pricing, calculation is done based on the distance between the service and the user;

- Responsive pricing, charging is activated only on service congestion;

- Session-oriented, based on the use given to the session;

- Usage-based, based on the general use of the service for a period of time, e.g. a month;

- Content-based, based on the accessed content;

- Location-based, based on the access point of the user;

- Service type, based on the usage of the service;

- Free of charge, no charge is applied for the services;

- Periodical fess, payment of time to time quantities for the use of a service;

- Pre-paid, the payment of the service is done in advance.

- Post-paid, the payment of the service is done after the use;

- Online, the accounting performed while the user makes use of a service;

- Offline, the accounting process is done after a service is used;

\section{A. Fixed Pricing}

Each service provider defines price for resources that could be prohibitive and thus lead to a reduced customer base and decrease in revenue and profits. Fixed pricing includes pricing mechanism as pay-per-use pricing, subscription and list price / menu price [14].

Pay-per-use pricing, users only have to pay for what they use. Customer pays in function of the time or quantity he consumes on a specific service. Pay-per-use makes users aware of the cost of doing business and consuming a resource.
In the following table are presented some of the pricing schemes for some providers for pay-per-use pricing mechanism [16].

TABLE I. PRICING SCHEMES FOR PAY-PER-USE

\begin{tabular}{|c|c|}
\hline Service & Pricing scheme \\
\hline $\begin{array}{l}\text { Amazon Web Services / } \\
\text { Elastic Compute Cloud } \\
\text { (EC2) }\end{array}$ & $\begin{array}{l}\text { - Charges on hourly for usage the } \\
\text { RAM, CPU } \\
\text { - Charge per transferred GB basis }\end{array}$ \\
\hline $\begin{array}{l}\text { Amazon Web Service / Simple } \\
\text { Storage Service (S3) }\end{array}$ & $\begin{array}{l}\text { - Charge per GB of storage } \\
\text { - Charge per data transferred in GB }\end{array}$ \\
\hline Microsoft Azure & $\begin{array}{c}\text { - Charge on hourly basis for processing } \\
\text { power and on per GB for storage }\end{array}$ \\
\hline $\begin{array}{l}\text { AppNexus / AppNexus Cloud } \\
\text { Source: appnexus.com }\end{array}$ & - Charge on hourly basis \\
\hline
\end{tabular}

Subscription pricing, users pay on a recurring basis to access software as an online service or to profit from a service.

The customer subscribes to use a preselected combination of service units for a fixed price and a longer time frame, usually monthly or yearly [15].

In the following table are presented some of the pricing schemes for some providers for subscription pricing mechanism.

TABLE II. PRICING SCHEMES FOR SUBSCRIPTION

\begin{tabular}{|c|c|}
\hline Service & Pricing scheme \\
\hline $\begin{array}{l}\text { Dropbox / Dropbox cloud } \\
\text { storage }\end{array}$ & Pricing assigned for stored in GB [17] \\
\hline Google / App Engine & $\begin{array}{l}\text { - Charges on monthly basis } \\
\text { - Charge per user basis } \\
\text { - Pricing on hourly basis }\end{array}$ \\
\hline $\begin{array}{l}\text { Amazon Web Services / } \\
\text { Elastic Compute Cloud } \\
(E C 2)\end{array}$ & It allows for the reservation of units \\
\hline Microsoft Azure & $\begin{array}{l}\text { - Charges on monthly basis, depending } \\
\text { from number of transactions } \\
\text { - Charges on monthly basis } \\
\text { subscription for database } \\
\text { Source: Microsoft Azure website }\end{array}$ \\
\hline Salesforce / Salesforce.com & $\begin{array}{l}\text { - price assigned on monthly basis per } \\
\text { user }\end{array}$ \\
\hline
\end{tabular}

Hybrid pricing model (pay-per-use plus subscription), in this model between per-per-use and subscription, dedicated servers must be provided in advance for a period of time [16].

In the following table are presented some of the pricing schemes for some providers for hybrid (pay-per-use plus subscription) pricing mechanism.

TABLE III. HYBRID PRICING SCHEMES

\begin{tabular}{|c|c|}
\hline Service & Pricing scheme \\
\hline Google / App Engine & $\begin{array}{l}\text { - Price assigned on monthly basis } \\
\text { - If limit exceeds then charge on per GB } \\
\text { and processing power on hourly basis }\end{array}$ \\
\hline $\begin{array}{l}\text { Joynet / Smart Machines } \\
\text { Source: joynet.com }\end{array}$ & $\begin{array}{l}\text { - Price assigned on monthly basis for the } \\
\text { package } \\
\text { - If the usage exceeds the limit the } \\
\text { charges on per GB }\end{array}$ \\
\hline
\end{tabular}


List Price / Menu Price, is a fixed price that is often found in a list or catalog.

\section{B. Dynamic Pricing}

The price is calculated based on pricing mechanism whenever there is a request. In some cases, the price of the resources is determined according to demand and supply [9]. As compared to fixed prices, the dynamic pricing that reflects the real-time supply demand relationship represents a more promising charge strategy that can better exploit user payment potentials and thus larger profit gains at the cloud provider [13].

\section{Market-Dependent Pricing}

Customer pays depending on the real-time market conditions and constraints. This schemes includes:

Bargaining, the price is determined on the basis of the relationship of the parties involved.

Yield Management, the best pricing policy for optimizing profits is calculated based on real-time modeling and forecasting of demand behavior [14].

Auction, is a negotiation mechanism which allows both parties to communicate and to agree on the offer. The price is set as buyers bid in increasing increments of price.

Dynamic Market, in that case buyers and sellers determine their price reference, but are not able to influence this price as individual sellers.

\section{PRICING Models In THE ClOUd}

The pricing in Cloud Computing has its root in system design and optimization. Resource's consumption based pricing is particularly sensitive to how a system is designed, configured, optimized, monitored, and measured. Cloud services vendors use a variety of pricing mechanisms, including usage-based fixed pricing, usage-based dynamic pricing, subscription-based pricing, reserved services contracts with a combination of usage-based fixed pricing and up-front fees, auction-based pricing, etc. [12].

Also pricing is more important in economic terms as fairness and competitive pricing in a multi-provider marketplace affect the actual pricing [10].

Pricing presents exchange process when customer/end user pays for services which have been offered by the service provider. Some of the most common factors affecting pricing in the cloud resources are presented in table IV.

Also there are other factors which affect the price in the cloud resources. These factors could be fixed or variable. Some of these factors that influence the price of cloud resources are presented in figure3.

Monitoring Service, few Cloud Providers have the confidence to provide customers with monitoring tools for service availability [28]. Monitoring services could be managed from the providers or a third party.
TABLE IV. MOST COMMON FACTORS THAT AFFECT IN PRICING

\begin{tabular}{|c|c|}
\hline $\begin{array}{l}\text { Initial Cost / } \\
\text { Investment }\end{array}$ & $\begin{array}{l}\text { Represent the amount of money that Cloud } \\
\text { service provider will spend per year, to buy a } \\
\text { resource. }\end{array}$ \\
\hline $\begin{array}{l}\text { Lease Period / } \\
\text { Contract Time }\end{array}$ & $\begin{array}{l}\text { It is the time in which the client will lease } \\
\text { resources from the cloud service provider. } \\
\text { Cloud service providers usually offer lower } \\
\text { unit prices for longer subscription periods. }\end{array}$ \\
\hline Quality of Service & $\begin{array}{l}\text { This factor represent the quality assurance } \\
\text { from cloud service provider for the customer. } \\
\text { The key aspects of quality of Service (QoS) } \\
\text { are: integrity of service provider, availability, } \\
\text { security, privacy, scalability. } \\
\text { For the better quality of service the price will } \\
\text { be higher. }\end{array}$ \\
\hline $\begin{array}{l}\text { Rate of depreciation } \\
\text { [3] }\end{array}$ & $\begin{array}{l}\text { It is the rate at which the hardware of service } \\
\text { provider is expected to lose its financial value. }\end{array}$ \\
\hline Age of Resources & $\begin{array}{l}\text { It represents the age of a particular resource the } \\
\text { service provider is leasing to the client [3]. }\end{array}$ \\
\hline Cost of Maintenance & $\begin{array}{l}\text { Represent the amount of money per year that } \\
\text { the cloud service provider spends to maintain } \\
\text { and secure the cloud. }\end{array}$ \\
\hline Monitoring Service & $\begin{array}{l}\text { Provider } \\
\text { Reputation }\end{array}$ \\
\hline $\begin{array}{l}\text { Social Category of } \\
\text { Customers }\end{array}$ & Public Review \\
\hline $\begin{array}{l}\text { Cost of Data } \\
\text { Center }\end{array}$ & Price \\
\hline User Reputation & $\begin{array}{c}\text { Type of Co-Cloud } \\
\text { Users }\end{array}$ \\
\hline
\end{tabular}

Fig. 3. Some factors that influence the price of cloud resources

Social Category of Customers, all clients should be offered a fair price, however, it should be viewed social aspect of clients or social classifications. Classification should be done depending on client's location.

Cost of Data Center, the price should be calculated for data centers, as cost of real estate, backup power, maintenance, cooling resources, network connectivity, security features etc.

User Reputation, the reputation of the users has a special importance in cloud services considering various attacks, sniffing programs, Trojans etc.

Provider Reputation, Cloud provider's reputation is also necessary to create a trust from the community when it is known that may have sensitive data. The reputation is the component of trust and it also measures reliability. Using Cloud infrastructure for critical business computation necessitate that the reputation of the Cloud provider is well established [28].

Public Review, public reviews on issues such as downtime, phishing, and data loss and password weakness can be valuable in pricing of cloud services [28]. 
SLA (Service Level Agreement) is a negotiated agreement for services between Cloud providers and cloud costumers. Most often SLAs are dictated by the Cloud Providers [29].

Co-Cloud Users, the nature of multi-tenancy in a Cloud could enable competitive companies to use the same Cloud platform. Information about co-tenants in the Cloud can be used to influence service price.

The service price could be affected if the information about co-tenants in the Cloud is used.

The table below compares some pricing model.

TABLE V. COMPARISON OF SOME PRICING MODELS

\begin{tabular}{|c|c|c|c|}
\hline $\begin{array}{l}\text { Pricing } \\
\text { Model }\end{array}$ & Description & $\begin{array}{l}\text { Features and } \\
\text { Fairness }\end{array}$ & $\begin{array}{l}\text { Implementati } \\
\text { on }\end{array}$ \\
\hline $\begin{array}{l}\text { Pay-as-you- } \\
\text { go [2] }\end{array}$ & $\begin{array}{l}\text { Price is set by } \\
\text { service provider } \\
\text { and remains } \\
\text { constant. This } \\
\text { model is static. }\end{array}$ & $\begin{array}{l}\text { Unfair to the client. } \\
\text { He might pay more } \\
\text { than necessary }\end{array}$ & $\begin{array}{l}\text { Implemented } \\
{[20,21]}\end{array}$ \\
\hline Subscription & $\begin{array}{l}\text { Price assigned } \\
\text { based on } \\
\text { subscription. This } \\
\text { model is static. }\end{array}$ & $\begin{array}{l}\text { According to this } \\
\text { model client } \\
\text { sometimes can } \\
\text { charge more or less. }\end{array}$ & $\begin{array}{l}\text { Implemented } \\
{[20,21]}\end{array}$ \\
\hline $\begin{array}{l}\text { Dynamic } \\
\text { Resource } \\
\text { Pricing [22] }\end{array}$ & $\begin{array}{l}\text { It is a dynamic } \\
\text { pricing model } \\
\text { used for federated } \\
\text { cloud and } \\
\text { supports various } \\
\text { resource types. }\end{array}$ & $\begin{array}{l}\text { In this model, } \\
\text { resource payments } \\
\text { are assigned based } \\
\text { on demand and } \\
\text { supply. }\end{array}$ & $\begin{array}{l}\text { Theoretical } \\
\text { study with } \\
\text { simulation }\end{array}$ \\
\hline $\begin{array}{l}\text { Pay-for- } \\
\text { resources }\end{array}$ & $\begin{array}{l}\text { This model } \\
\text { (static) is cost } \\
\text { based. Offers } \\
\text { maximum } \\
\text { utilization for } \\
\text { resources }\end{array}$ & $\begin{array}{l}\text { Is fair for client and } \\
\text { cloud service } \\
\text { providers. }\end{array}$ & $\begin{array}{l}\text { Implemented } \\
{[20,21] .} \\
\text { It is hard to } \\
\text { implement. }\end{array}$ \\
\hline $\begin{array}{l}\text { Hybrid } \\
\text { pricing }\end{array}$ & $\begin{array}{l}\text { Price changed } \\
\text { according to the } \\
\text { job queue wait } \\
\text { times [2] }\end{array}$ & $\begin{array}{l}\text { This model is fair to } \\
\text { clients. }\end{array}$ & $\begin{array}{l}\text { The model is } \\
\text { implemented }\end{array}$ \\
\hline $\begin{array}{l}\text { Dynamic } \\
\text { Auction [23] }\end{array}$ & $\begin{array}{l}\text { This model based } \\
\text { on truthfulness } \\
\text { and dynamic } \\
\text { adjustment. }\end{array}$ & $\begin{array}{l}\text { Tolerate fluctuation } \\
\text { of users' } \\
\text { distributions. }\end{array}$ & $\begin{array}{l}\text { Theoretical } \\
\text { study with } \\
\text { simulation }\end{array}$ \\
\hline $\begin{array}{l}\text { Double } \\
\text { Auction } \\
\text { Bayesian } \\
\text { Game-Based } \\
{[24]}\end{array}$ & $\begin{array}{l}\text { This model } \\
\text { enables } \\
\text { people to buy } \\
\text { resources } \\
\text { from various } \\
\text { providers }\end{array}$ & $\begin{array}{l}\text { Free resources can } \\
\text { be exchanged with } \\
\text { more flexibility. }\end{array}$ & $\begin{array}{l}\text { Theoretical } \\
\text { study. }\end{array}$ \\
\hline $\begin{array}{l}\text { Double sided } \\
\text { Combination } \\
\text { al Auctions } \\
\text { to Resource } \\
\text { Allocation [ } \\
9,25]\end{array}$ & $\begin{array}{l}\text { This model is for } \\
\text { service allocation } \\
\text { that enables users } \\
\text { and providers to } \\
\text { deal through } \\
\text { double-sided } \\
\text { combinational } \\
\text { auction. }\end{array}$ & $\begin{array}{l}\text { Users and service } \\
\text { providers should be } \\
\text { satisfied by the } \\
\text { resource allocation } \\
\text { mechanism. }\end{array}$ & $\begin{array}{l}\text { Theoretical } \\
\text { study with } \\
\text { simulation }\end{array}$ \\
\hline $\begin{array}{l}\text { Pricing } \\
\text { algorithm for } \\
\text { cloud } \\
\text { computing } \\
\text { resources } \\
\text { [19] }\end{array}$ & $\begin{array}{l}\text { This model based } \\
\text { on real time } \\
\text { pricing. } \\
\text { This model is } \\
\text { dynamic. }\end{array}$ & $\begin{array}{l}\text { Fair for provider } \\
\text { because it reduces } \\
\text { costs and maximizes } \\
\text { revenues }\end{array}$ & $\begin{array}{l}\text { Theoretical } \\
\text { study with } \\
\text { simulation }\end{array}$ \\
\hline
\end{tabular}

\begin{tabular}{|c|c|c|c|}
\hline $\begin{array}{l}\text { Genetic } \\
\text { model for } \\
\text { pricing in } \\
\text { cloud } \\
\text { computing } \\
\text { markets [8] }\end{array}$ & $\begin{array}{l}\text { This model based } \\
\text { on real time } \\
\text { pricing. } \\
\text { This model is } \\
\text { dynamic. }\end{array}$ & $\begin{array}{l}\text { The algorithm } \\
\text { increasing revenues } \\
\text { for service } \\
\text { providers. }\end{array}$ & $\begin{array}{l}\text { Theoretical } \\
\text { study with } \\
\text { simulation }\end{array}$ \\
\hline $\begin{array}{l}\text { Value-based } \\
\text { pricing }\end{array}$ & $\begin{array}{l}\text { Price assigned on } \\
\text { client's perceive } \\
\text { basis. This model } \\
\text { is dynamic. }\end{array}$ & $\begin{array}{l}\text { Fair to producers } \\
\text { where prices are set } \\
\text { on the value } \\
\text { perceived by the } \\
\text { client }\end{array}$ & $\begin{array}{l}\text { The model is } \\
\text { implemented }\end{array}$ \\
\hline $\begin{array}{l}\text { Cost-based } \\
\text { pricing [26] }\end{array}$ & $\begin{array}{l}\text { In this model the } \\
\text { priority is to } \\
\text { increase the } \\
\text { profit. }\end{array}$ & $\begin{array}{l}\text { It is not difficult to } \\
\text { calculate the price. } \\
\text { Client role is not } \\
\text { primary. }\end{array}$ & $\begin{array}{l}\text { The model is } \\
\text { implemented }\end{array}$ \\
\hline $\begin{array}{l}\text { Competition- } \\
\text { based pricing } \\
{[27]}\end{array}$ & $\begin{array}{l}\text { Price assigned } \\
\text { according to } \\
\text { competitors' } \\
\text { prices. This model } \\
\text { is dynamic. }\end{array}$ & $\begin{array}{l}\text { The model is fair to } \\
\text { clients if the price is } \\
\text { assigned on the } \\
\text { basis of } \\
\text { competition. }\end{array}$ & $\begin{array}{l}\text { The model is } \\
\text { implemented }\end{array}$ \\
\hline $\begin{array}{l}\text { Customer- } \\
\text { based pricing } \\
{[11]}\end{array}$ & $\begin{array}{l}\text { Price assigned } \\
\text { according to what } \\
\text { client want and } \\
\text { the need to pay. }\end{array}$ & $\begin{array}{l}\text { This model is fair } \\
\text { for clients if there } \\
\text { are taken into } \\
\text { account. }\end{array}$ & $\begin{array}{l}\text { The model is } \\
\text { implemented }\end{array}$ \\
\hline $\begin{array}{l}\text { A novel } \\
\text { financial } \\
\text { economic } \\
\text { model [3] }\end{array}$ & $\begin{array}{l}\text { This model is } \\
\text { dynamic, which } \\
\text { based on usage. }\end{array}$ & $\begin{array}{l}\text { Is fair for service } \\
\text { provider and client. } \\
\text { Provides a high } \\
\text { level of Quality of } \\
\text { Service for clients. }\end{array}$ & $\begin{array}{l}\text { Theoretical } \\
\text { study with } \\
\text { simulation }\end{array}$ \\
\hline
\end{tabular}

The following we present some pricing structure examples for some services.

An example of IaaS is Amazon S3, which is an online storage web service offered by Amazon Web Services. Amazon Web Services uses Amazon Spot Instances to allow customers to bid for their unused capacity. Amazon runs the customer's instances as long as the bid price is higher than the spot price, which is set by Amazon based on their data center utilization [15].

The pricing structure (pay-per-use pricing) of several Amazon S3 services is shown in the table below.

TABLE VI. AMAZON S3 PRICING

\begin{tabular}{|l|l|l|}
\cline { 2 - 3 } \multicolumn{1}{c|}{} & $\begin{array}{l}\text { Standard } \\
\text { Storage }\end{array}$ & $\begin{array}{l}\text { Reduced } \\
\text { redundancy } \\
\text { Storage }\end{array}$ \\
\hline First $1 \mathrm{~TB} /$ month & $\$ 0.0390$ per GB & $\$ 0.0312$ per GB \\
\hline Next $49 \mathrm{~TB} /$ month & $\$ 0.0383$ per GB & $\$ 0.0306$ per GB \\
\hline Next $450 \mathrm{~TB} /$ month & $\$ 0.0377$ per GB & $\$ 0.0301$ per GB \\
\hline Next $500 \mathrm{~TB} /$ month & $\$ 0.0370$ per GB & $\$ 0.0296$ per GB \\
\hline Next $4000 \mathrm{~TB} /$ month & $\$ 0.0364$ per GB & $\$ 0.0291$ per GB \\
\hline Over $5000 \mathrm{~TB} /$ month & $\$ 0.0357$ per GB & $\$ 0.0285$ per GB \\
\hline
\end{tabular}

Source: Amazon website

An another example of PaaS is Google App Engine which is a platform for developing and hosting web applications in data centers who are managed by Google.

The pricing structure (pay-per-use pricing) for Google AppEngine is shown in the table below.

Another example of SaaS is Sales Cloud which provides some features as sales representatives with a complete customer profile and account history. It enables users for decision makers, to manage marketing campaign and other information for the company's sales process. 
TABLE VII. GOOGLE APPENGINE PRICING

\begin{tabular}{|l|l|l|}
\hline Resource & Unit & Unit cost \\
\hline Frontend Instances & Instance hours & $\begin{array}{l}\$ 0.05 / \$ 0.10 / \$ 0 . \\
20 / \$ 0.30\end{array}$ \\
\hline Outgoing Network Traffic & Gigabytes & $\$ 0.12$ \\
\hline Datastore Storage & Gigabytes per month & $\$ 0.18$ \\
\hline Dedicated Memcache & Gigabytes per hour & $\$ 0.06$ \\
\hline $\begin{array}{l}\text { Blobstore, Logs, and Task } \\
\text { Queue Stored Data }\end{array}$ & Gigabytes per month & $\$ 0.026$ \\
\hline Logs API & Gigabytes & $\$ 0.12$ \\
\hline
\end{tabular}

Source: Google Cloud Platform / App Engine Pricing below.

The pricing structure for Sales Cloud is shown in the table

TABLE VIII. SALES CLOUd PRICING

\begin{tabular}{|l|l|l|}
\hline Product & Description & $\begin{array}{l}\text { Price (per user per } \\
\text { month) }\end{array}$ \\
\hline Contact Manager & $\begin{array}{l}\text { Contact management } \\
\text { for up to 5 users }\end{array}$ & $\$ 5$ \\
\hline Group & $\begin{array}{l}\text { Basic sales \& } \\
\text { marketing for up to 5 } \\
\text { users }\end{array}$ & $\$ 25$ \\
\hline Professional & $\begin{array}{l}\text { Complete CRM for } \\
\text { any size team }\end{array}$ & $\$ 65$ \\
\hline Enterprise & $\begin{array}{l}\text { Customize CRM for } \\
\text { entire business }\end{array}$ & $\$ 125$ \\
\hline Unlimited & $\begin{array}{l}\text { Unlimited CRM power } \\
\text { and support }\end{array}$ & $\$ 250$ \\
\hline
\end{tabular}

Source: salesforce.com

An another example of PaaS and SaaS is Microsoft Windows Azure as a Cloud Computing platform and infrastructure for building, deploying and managing applications and services in datacenters. The pricing structure for Windows Azure block blobs is shown in the table below.

TABLE IX. WINDOWS AZURE PRICING

\begin{tabular}{|c|c|c|c|}
\hline $\begin{array}{l}\text { Storage } \\
\text { Capacity }\end{array}$ & $\begin{array}{l}\text { Locally } \\
\text { Redundant } \\
\text { Storage }\end{array}$ & $\begin{array}{l}\text { Zone } \\
\text { Redundant } \\
\text { Storage } \\
\end{array}$ & $\begin{array}{l}\text { Geographical } \\
\text { ly Redundant } \\
\text { Storage }\end{array}$ \\
\hline $\begin{array}{l}\text { First } 1 \text { TB / } \\
\text { Month }\end{array}$ & $\begin{array}{l}\$ 0.024 \text { per } \\
\text { GB }\end{array}$ & $\$ 0.03$ per $\mathrm{GB}$ & $\begin{array}{l}\$ 0.048 \text { per } \\
\text { GB }\end{array}$ \\
\hline $\begin{array}{l}\text { Next } 49 \text { TB (1 } \\
\text { to } 50 \mathrm{~TB}) / \\
\text { Month }\end{array}$ & $\begin{array}{l}\$ 0.0236 \text { per } \\
\text { GB }\end{array}$ & $\$ 0.0295$ per GB & $\begin{array}{l}\$ 0.0472 \text { per } \\
\text { GB }\end{array}$ \\
\hline $\begin{array}{l}\text { Next } 450 \mathrm{~TB} \\
(50 \text { to } 500 \mathrm{~TB}) / \\
\text { Month }\end{array}$ & $\begin{array}{l}\$ 0.0232 \text { per } \\
\text { GB }\end{array}$ & $\$ 0.029$ per GB & $\begin{array}{l}\$ 0.0464 \text { per } \\
\text { GB }\end{array}$ \\
\hline $\begin{array}{l}\text { Next } 500 \mathrm{~TB} \\
\text { (500 to } 1,000 \\
\text { TB) / Month }\end{array}$ & $\begin{array}{l}\$ 0.0228 \text { per } \\
\text { GB }\end{array}$ & $\$ 0.0285$ per GB & $\begin{array}{l}\$ 0.0456 \text { per } \\
\text { GB }\end{array}$ \\
\hline $\begin{array}{l}\text { Next } 4,000 \text { TB } \\
(1,000 \text { to } 5,000 \\
\text { TB) / Month }\end{array}$ & $\begin{array}{l}\$ 0.0224 \text { per } \\
\text { GB }\end{array}$ & $\$ 0.028$ per GB & $\begin{array}{l}\$ 0.0448 \text { per } \\
\text { GB }\end{array}$ \\
\hline
\end{tabular}

Source: azure.microsoft.com

\section{CONCLUSIONS}

In this paper we have reviewed and discussed some basic concepts for the pricing schemes and models in Cloud Computing.

Also we made some comparisons between recent pricing schemes and models which are implemented by providers.
Each of the pricing schemes have advantages and their disadvantages, which often can be unfavorable to customers.

Future work must address the changes in risk sharing model between services provider and customer.

In the future a major consideration should be towards the development of an efficient and adequate pricing mechanism that will meet even more customer's requirements.

\section{REFERENCES}

[1] I. Foster, I. Yong, Z. Raicu and S. Lu, Cloud Computing and Grid Computing 360-Degree Compared, Grid Computing Environments Workshop, 2008

[2] M. Al-Roomi, Sh. Al-Ebrahim, S. Buqrais and I. Ahmad, Cloud Computing Pricing Models: A Survey, International Journal of Grid and Distributed Computing Vol.6, No.5, pp.93-106, 2013.

[3] B. Sharma, R. K. Thulasiram, P. Thulasiraman, S. K. Garg and R. Buyya, Pricing Cloud Compute Commodities: A Novel Financial Economic Model, Proc. of IEEE/ACM Int. Symp. on Cluster, Cloud and Grid Computing, 2012.

[4] C. D. Patel and A. J. Shah, Cost model for planning, development and operation of a data center, hp technical report- hpl-2005-107(r.1), 2005.

[5] Pal, R. and Hui, P., Economic models for cloud service markets: Pricing and Capacity planning. Theoretical Computer Science 496, 113-124, July. 2013.

[6] W. Wang, P. Zhang, T. Lan and V. Aggarwal, Datacenter Net Profit Optimization with Individual Job Deadlines, Proc. Conference on Inform. Sciences and Systems 2012.

[7] C. S. Yeoa, S. Venugopalb, X. Chua and R. Buyyaa, Autonomic Metered Pricing for a Utility Computing Service, Future Generation Computer Syst., vol. 26, no. 8, 2010.

[8] M. Macias and J. Guitart, A Genetic Model for Pricing in Cloud Computing Markets, Proc. $26^{\text {th }}$ Symp. of Applied Computing, 2011.

[9] P. Samimi and A. Patel, Review of Pricing Models for Grid \& Cloud Computing, IEEE Symposium \& Informatics, 2011.

[10] H. Wang, Q. Jing, R. Chen, B. He, Zh. Qian and L. Zhou, Distributed Systems Meet Economics: Pricing in the Cloud, Inproceedings, HotCloud '10, June 2010.

[11] I. R-Agundez, Y. K. Penya and P. G. Bringas, A Flexible Accounting Model for Cloud Computing, Annual SRII Global Conference, 2011.

[12] J. Huang, Pricing Strategy for Cloud Computing Services, PACIS Proceedings, paper 279, 2013.

[13] J. Zhao, H. Li, C. Wu, Z. Li, Z. Zhang, F. C.M. Lau, Dynamic Pricing and Profit Maximization for the Cloud with Geo-distributed Data Centers, INFOCOM, Proceedings IEEE, 2014.

[14] J. Jäätmaa, Financial aspects of cloud computing business models, Aalto University, master's thesis, 2010.

[15] S. Chun and B.S. Choi, Service models and pricing schemes for cloud computing, Springer Science + Business Media New York 2013.

[16] S. Kansal, G. Singh, H. Kumar and S. Kaushal, Pricing Models in Cloud Computing, Proceedings of the 2014 International Conference on Information and Communication Technology for Competitive Strategies, ACM, 2014.

[17] Cloud Storage Providers: Comparison of Features And Prices, http://www.tomshardware.com/reviews/cloud-storage-providercomparison,3905-3.html.

[18] H. Wang, Q. Jing, R. Chen, B. He, Zh. Qian and L. Zhou, Distributed Systems Meet Economics: Pricing in the Cloud, HotCloud '10, June 2010.

[19] H. Li, J. Liu and G. Tang, A Pricing Algorithm for Cloud Computing Resources, Proc. Int. Conference on Network Computing and Inform. Security, 2011.

[20] Amazon Web Services, http://aws.amazon.com/, last accessed 10.12.2015.

[21] Google App Engine, https://cloud.google.com/appengine/, last accessed 11.12.2015. 
[22] M. Mihailescu and Y.M. Teo, Dynamic Resource Pricing on Federated Clouds, 10th IEEE/ACM International Conference on Cluster, Cloud and Grid Computing, 2010.

[23] W.-Y. Lin, G.-Y. Lin, and H.-Y. Wei, Dynamic Auction Mechanism for Cloud Resource Allocation, Cluster, Cloud and Grid Computing, 10th IEEE/ACM, 2010.

[24] S. Shang, J. Jiang, Y. Wu, Z. Huang, G. Yang, and W. Zheng, DABGPM: A Double Auction Bayesian Game-Based Pricing Model in Cloud Market, Network and Parallel Computing, 2010.

[25] I. Fujiwara, K. Aida and I. Ono, Applying Double-sided Combinational Auctions to Resource Allocation in Cloud Computing, 10th Annual International Symposium on Applications and the Internet, 2010.

[26] S. Lehmann and P. Buxmann, Pricing Strategies of Software Vendors, Business and Information Systems Engineering, 2009.
[27] J. Rohitratana and J. Altmann, Agent-Based Simulations of the Software Market under Different Pricing Schemes for Software-as-a-Service and Perpetual Software, Economics of Grids, Clouds, Systems, and Services, ser. Lecture Notes in Computer Science, Springer, 2010.

[28] S. A.Bello, C. L“uthje and C. Reich, Cloud Resource Price System, The Sixth International Conference on Emerging Network Intelligence, Emerging 2014.

[29] P. Hofmann and D. Woods, Cloud computing: The limits of public clouds for business applications, IEEE Internet Computing, vol. 14, no. $6,2010$.

[30] M. Jaekel and A. Luhn, Cloud Computing - Business Models, Value Creation Dynamics and Advantages for Customers. White Paper. Siemens IT Solutions and Services, 2009 